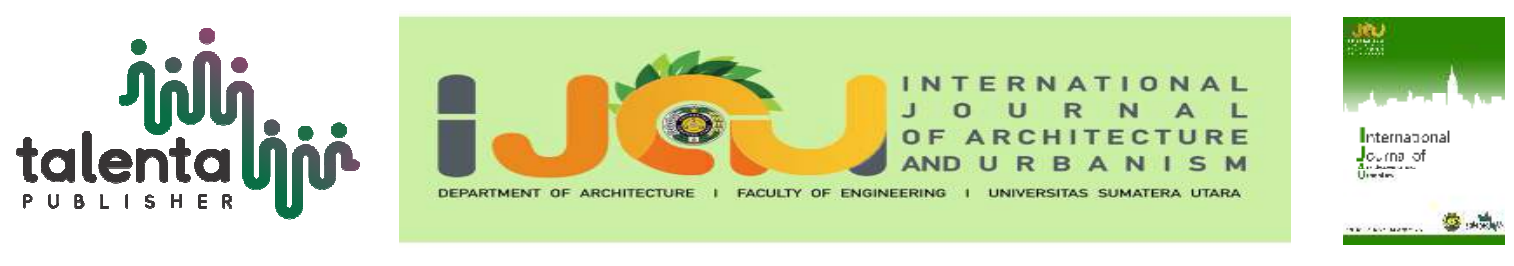

\title{
The Impact Singer \& Jipen of Dayak Tribe on Environmental Sustainability in Central of Borneo
}

\author{
Muh. Azhari ${ }^{1}$ \\ ${ }^{1}$ Universitas Muhammadiyah Palangka Raya
}

\begin{abstract}
The environment is a mandate that must be maintained, because a good environment will produce a generation that is good and strong. Poor environmental management will create new problems. Ethics that regulate environmental management can maintain environmental conditions and reduce the rate of environmental change, for example by the presence of singer and jipen owned by the Central Of Borneo Dayak Tribe. Singer is a punishment and jipen is the amount of customary punishment given to someone who commits a customary offense. A detrimental activity will distrub the productivity of the environment, with the singer and jipen will be able to reduce the rate of damage. Case examples of the application of singer and jipen such as the Wilmar Group case, productive Durian Tree Cutting, Murder, even defamation, singer and jipen giving in accordance with the impact of the case, whether it is detrimental on a small or large scale and determined. The sentence was determined by the kepala adat / mantir / demang. The research used is a type of ethnography with data collection techniques by observation, interviews and literature studies.
\end{abstract}

Keyword: environmental, dayak tribe, jipen, singer

\section{Introduction}

\section{Background of Research}

The environment and needs of human life cannot be separated from each other, these needs are in the form of clothing, food and board needs. All of these needs come from nature, so that the environment must be maintained properly such as a friend, relative, or like a parent who looks after and protects his children. The environment without humans will continue in a good and stable condition but on the contrary humans without a good environment, will affect the quality of human life itself, both from health, economy, and social.

Changes in the function of the natural environment because human needs continue to increase, causing a decline in the quality of the environment that is very fast and detrimental to living things that cannot be adapted to these conditions. Changes in the function of the natural

*Corresponding author at: [Jl. RTA Milono km 1.5, Langkai, Pahandut, Kota Palangka Raya, Kalimantan Tengah 73111]

E-mail address: arymuh84@gmail.com 
environment, for example, are plantations, transmigration land, residential development and housing and other infrastructure developments.

These activities have the potential to sustain the lives of Flora and Fauna that grow in the natural environment. Biodiversity can be threatened with extinction, especially when it comes to living things endemic to the area, for example Kalimantan Island which is considered to still have a natural forest environment is rarely found, even if there are only a few parts left.

The impact of activities on the conversion of natural environments such as forests, for example, influences the microclimate around forests, land and rainwater catchments. If humans change the natural environment around them without rules that support environmental sustainability, humans will feel unwanted effects and will regret after a disaster in the future.

Environmental exploitation activities that cause loss value must be felt by humans. Humans will try to improve the condition of the natural environment which is decreasing with recovery activities. Of course, these activities require cost, time and thought to implement them, before that happens it would be good to make a wise decision in acting related to environmental management, because the environment has limits of ability, has a saturation point to survive from unfavorable and unfavorable conditions ( principle to four environment).

Communities consciously experience a lot of losing value that cannot be broken, the price to be paid from activities that do not consider the long-term impact of these activities, for example from the burning of forest land and gardens, the effects of haze arising from burning activities, illegal logging, illegal mining, and free fishing. Fish and animals that are often encountered and easily obtain it now begin to be difficult to find even to get it there is a nominal price that must be spent, for that environment both in the form of natural environment, artificial environment, social environment must be maintained properly, it aims to preserve the environment for example, by making rules that must be adhered to by the community, both local communities and immigrants and the government. The rules are like the legacy of the Dayak Kalimantan singer and jipen community which is useful for preserving the environment, both now and in the future.

\section{Formulation of the Problem}

Problem formulation in the research are:

1. How are the singer and jipen forms given to the community that damage the environment?

2. Who has the right to determine the singer and jipen punishment for people who damage the environment? 


\section{Research Purposes}

The intended purpose is to answer the formulation of existing problems, including:

1. To find out the singer and jipen forms that are given to people who damage the environment.

2. To find out about who has the right to determine singer and jipen punishment for people who damage the environment.

\section{Literature Review}

\section{Environmental}

Environment is a complete system that is outside the individual that affects the growth and development of organisms. Environment is not the same as habitat. Habitat is a place where the organism or community of living organisms [12]. Environment is an integrated system between abiotic and biotic components, both of which are in a condition of compensative relationships and produce system harmony. Environment is a system in which the subsystems work both abiotic and biotic subsystems and the process of transformation and translocation is triggered by the process of exchanging energy and material / material between the subsystems. Abiotic subsystems include the atmosphere, pedhosfer / lithosphere and hydrosphere, while the biotic subsystem is all living things or organisms with all forms of interaction that occur [3].

In the book Environmental Theology [1] environment as a condition or natural condition consisting of living things and non-living things that are on earth or parts of the earth naturally and interconnected with one another others.

\section{Dayak Tribe}

Nila Riwut, 2003 said that Kalimantan is the largest island that has large rivers and the third largest island after Green Land and Irian Jaya. As western colonialism, the former British territory in the north became the territory of Malaysia and the King of Brunei, while the former Dutch colony in the south became the territory of the Republic of Indonesia which was divided into four provinces, namely West Kalimantan, East Kalimantan, South Kalimantan and Central Kalimantan. The word Dayak is a common term in Kalimantan even throughout Indonesia, everyone who speaks the word Dayak is certainly looking at one of the tribes in Indonesia who inhabit Borneo. There are differences of opinion about the Dayak tribe originating from the seventh sky and some who depend on the Dayak people from proto melayu. According to the Dayak beliefs that come from the belief in kaharingan, humans are descended from the seventh heaven in four places, namely:

1. In the Tantan Puruk Pamatuan, which is located on the Kahayan and Barito Rivers 
2. In Tantang Liang Mangan Puruk Kaminting which is located around Gunung Raya.

3. In Datah Tangkasiang, on the contrary upstream of the river, which is located in West Kalimantan.

4. In Puruk Kambang Tanah Siang which is located on the Barito River.

Dayaks descended on these places, marry each other, then breed collect all of the island of Borneo. More scientifically less than two hundred years after masehi, there was the first movement of the nation to Indonesia. They came as a whole from the Yunan area.

The Dayaks are predominantly living in the interior and not many inhabit the Coastal area. Each tribe has its own language, even the regional languages of the tribes in a distant area are also different. For example, in the Kahayan and Kapuas areas from the river mouth to approximately two parts on the Kahayan River, the population uses Dayak Ngaju language. Meanwhile in the upstream section, the language used is the Otak Dayak language. Danom. The Dayak tribe in Kalimantan consists of seven tribes. The seven tribes consisted of eighteen tribes of young children, consisting of 405 tribes.

\section{Singer \& Jipen}

Singer or punishment given to the guilty person, the sentence is in the form of customary punishment. Initially singer was intended for victims and perpetrators but now only pay court fees [9]. Article singer or the sentence that has been set amounted to 96 articles, the articles become references for demang / adat head to determine customary punishment for the suspects, while Jipen is a unit of punishment for violations or punishment given to someone who violates customary law.

If the case is led by a demang, the claimant must pay Rp. 5 (Golden currency equivalent) to Demang with cash. However, it may also be estimated according to the price in general. If the case is led by a pembakal, then the claimant is obliged to pay a table of Rp 2.5 in the form of cash may be replaced with goods according to the price in general [10].

\section{Methodology}

The location of the study was carried out in Central Kalimantan. The Dayak tribe that dominates Central Kalimantan is the Dayak Ngaju tribe. Ngaju is one of the ethnic groups of the Dayaks, who inhabit the island of Borneo. Ngaju people live in Central Kalimantan Province. The distribution of the Ngaju Dayak Tribe covers several districts, namely Kapuas District, South Barito, North Barito, East Kotawaringin, West Kotawaringin, Katingan, Gunung Mas and Palangka Raya City. The Ngaju Dayak tribe is the largest Dayak group compared to other groups in Central Kalimantan Province [5]. 


\section{Types of Research}

The type of research used in the study entitled "the Impact Singer and Jipen of Dayak Tribe on Environmental Sustainability in Central of Borneo" is a type of ethnographic research. Ethnographic type research is one of the qualitative research strategies in which researchers investigate a group of cultures in a natural environment for a considerable period of time in collecting primary data, observation data and interview data [4]. Ethnography as a description of a culture, to understand a view of life from the perspective of indigenous people, even ethnography emphasizes the importance of the central role of culture in understanding the way of life of the groups studied [2].

\section{Data Collection Technique}

Data collection techniques used in research activities are observations, interviews and literature study studies. Observation data collection techniques is a technique of data collection carried out by making direct observations on the object of research to obtain the desired data [11]. Interview technique is a technique of data collection by communicating with data sources, both directly and indirectly, while data collection by using literature study references aims to produce information about the data that you want to collect [13].

\section{Result and Discussion}

Based on the data obtained related to singer and jipen owned by the Central Kalimantan Dayak Tribe Associated with customary punishment for environmental problems such as the case:

1. DAD (Dayak Adat Council) Kotawaringin Barat Regency Imposes sanctions for custom penalties of 2 guci antik, 15 belanga (worth 30 million) to Mayor kal Fatkur Arifin on cases of social environment (beating) [6].

2. Violation on February 10, 2018 by PT. Mustika Sembuluh belongs to the Wilmar Group which damaged the Customary Site and Houses of Residents in the District. North Mentaya, East Kotawaringin for Rp. 577,777,777 [7].

3. Case of Dayak Tribe Breaking by Prof. Dr. Thamrin Amal Tomagola in the form of 5 Pikul Gong and Money of Rp. 87,000,000 [14].

4. Penalties to PT Sawit Mandiri Lestari (SML) for damaging customary forests in the district. Lam Kwa Batang amounting to Rp.5,000,000,000 [8].

5. Penalties for burning or cutting down productive durian trees in Kota Pangkut Kotawaringin Barat in the amount of Rp. 3,500,000 
6. Penalties for those who poison / try fish in the river area of Pangkut Kotawaringin Barat in the amount of Rp. 5,000,000

The distribution of singer and jipen in various regions in Central Kalimantan varies depending on the problems faced, the decision of the singer's giving depends on the agreement between the mantir / damang/ketua adat based on the existing singer articles, for the jipen itself depending on the agreement of the ketua adat.

The environment is related to the pattern of life, patterns of thinking and behavior of the people who inhabit the area, for example people who inhabit the area of Central Kalimantan with a type of hot area, rich in natural resources and possessing peat swamp areas.

Forest is the mother of the Dayak tribe, what is asked to fulfill their daily needs in the form of clothing, food and shelter will also be given, it is not surprising that every region in Central Kalimantan has customary forests, but along with the increasing needs of life causes many Customary forests are exploited by landscapes into production forests such as oil palm plantations, rubber plantations and sengon gardens.

Changes in the function of the land promises good expectations for the community, both around the place of implementation of the activity. Desired expectations can improve economic performance and social welfare through activities carried out by the company. For example the recruitment of local labor and CSR programs made by the company. The expected impact of environmental management activities into plantation areas is not always positive, but it has a negative impact, one of them is the problem between land owners (companies / plantations / industry) and surrounding communities, such as the case of destruction of custom sites by Wilmar Group (PT Mustika Ten) and other cases.

Wealth must be maintained and protected, so that what is currently available can be enjoyed by future generations based on the goals of a sustainable environment. Things to be achieved in a sustainable environmental program include balancing three pillars such as environmental, economic and social pillars [15].

Balancing the three pillars, for example by applying singer and jipen to the people that are detrimental to the local environment, both harms the natural environment and the social and environmental environment of the Dayak tribe. Customary or singer punishment is based on the results of the adat session and refers to existing singer articles.

Giving punishment and the amount is intended to keep the environment in Central Kalimantan maintained, so that it can give deterrent effect to the perpetrators, along with the ketua adat, mantir, or demang and Dayak tribesmen must struggle to maintain the existing singer rules, such as those delivered by A2012cep Akbar in 2011 about jipen, that Jipen in Central Kalimantan 
experienced a decline in values along with the mixing of community culture, education, technology and religion.

Singers and jipen that have been set up are indeed unable to replace the value lost from loss activities carried out by a group of people or someone, the price in nominal terms given is not the main goal of the customary head and community, but for the environment (natural, artificial and social) maintain well for the sake of preserving its sustainability as a shared property that will never be lost.

The third environmental principle states that existing materials, energy, space, plants and animals are included in the category of natural resources. The hope of a singer and jipen will continue to be a protector of existing natural wealth, the bird of Tinggang beautiful, the distinctive Durian Kalimantan fruit, and Kayu Hitam / Ulin which are starting to become scarce and other resources will remain as an endless inheritance it even becomes an invaluable regional identity, and the forest remains a place to meet daily needs without having to buy rupiah coffers

\section{Conclusion}

The singer and jipen form given by the kepala adat / mantir / demang is either in the form of objects or money. The fine aims to provide deterrent effects and provide awareness for the perpetrators

Singers and jipen need to be maintained properly so that the surrounding environment is maintained and remains productive in meeting human needs. Determination of penalties and their nominal and type of violations need to be discussed so that there is no difference between singer and jipen types in each case that occurs in various areas of Central Kalimantan.

\section{REFERENCE}

[1] A. A, Studi Kearifan Lokal Penggunaan Api Persiapan Lahan Studi Kasus di Hutan Mawas Kalimantan Tengah vol. 8, no. 3, pp. 211-230, Jurnal Penelitian Sosial dan Ekonomi Kehutanan, 2011.

[2] Batuadji.k, Thesis As Mokshartham Jagadhita; Studi Etnografis Tentang Well Being pada Warga Asram Gandhi Etnis Bali., Yogyakarta: Fakultas Psikologi UGM, 2009.

[3] S. Budiastuti, Ekologi Umum Teori Dasar Pengelolaan Lingkungan, Solo: UNS Press, 2010 .

[4] Creswell.J, Research Design Pendekatan Kualitatif, Kuantitatif dan Mixed cetakan ke 2, Yogyakarta: Pustaka Pelajar, 2012.

[5] J. M, Ensiklopedi Suku Bangsa di Indonesia Jilid L-Z, Jakarta: Direktorat Jendral Kebudayaan, 1995. 
[6] N. B. Baskoro, "Sidang adat Dayak, Perwira TNI AU didenda 2 Guci antik dan 15 Belanga. Sabtu 17 Juni 2017.," kompas.com, 176 2017. [Online]. Available:

https://regional.kompas.com/read/2017/06/17/13525861/sidang.adat.dayak.perwira.tni.au.di denda.2.guci.antik.dan.15.belanga. [Diakses 17 June 2017].

[7] R. K, "Rusak Situs Adat Dayak, Perusahaan Sawit didenda Setengah Miliar," Liputan6.com, 15 Mei 2018. [Online]. Available:

https://www.liputan6.com/regional/read/3525324/rusak-situs-adat-dayak-perusahaan-sawitdidenda-setengah-miliar-rupiah. [Diakses 15 Mei 2018].

[8] L. Arumingtyas, "Begini Nasib Hutan Adat Laman Kinipan kala Investasi Sawit Datang," Mongabay.com, 18 June 2018. [Online]. Available:

https://www.mongabay.co.id/2018/06/18/begini-nasib-hutan-adat-laman-kinipan-kalainvestasi-sawit-datang/. [Diakses 18 June 2018].

[9] N. R, Manesr Panatau Tatu Hiang Menyelami Kekayaan Leluhur, Yogyakarta: Pusaka Lima, 2003.

[10] N. R, Kalimantan Membangun Alam dan Kebudayaan, Yogyakarta: NR Publishing, 2007.

[11] Riduwan, Metode Riset, Jakarta: Rineka Cipta, 2004.

[12] S. P, Cakrawala Memahami Lingkungan, Solo: UNS Press, 2008.

[13] Sukandarrumidi, Metodelogi Penelitian Petunjuk Praktis untuk Peneliti pemula., Yogyakarta: Gadjah Mada University Press, 2006.

[14] K. WW, "Majelis Adat dayak Vonis Thamrin Amal Tomagola Bersalah," tempo.co, 22 January 2011. [Online]. Available: https://nasional.tempo.co/read/308179/majelis-adatdayak-vonis-thamrin-amal-tomagola-bersalah. [Diakses 22 January 2011].

[15] United Nations Confrence on Sustainable Development, Rio de Janeiro, 2009. 